\title{
The Helper Component Proteinase Cistron of Potato virus $Y$ Induces Hypersensitivity and Resistance in Potato Genotypes Carrying Dominant Resistance Genes on Chromosome IV
}

\author{
Benoît Moury, ${ }^{1}$ Bernard Caromel, ${ }^{2}$ Elisabeth Johansen, ${ }^{3}$ Vincent Simon, ${ }^{1}$ Laura Chauvin, ${ }^{4}$ \\ Emmanuel Jacquot, ${ }^{5}$ Camille Kerlan, ${ }^{5}$ and Véronique Lefebvre ${ }^{2}$ \\ ${ }^{1}$ INRA, UR407 Pathologie Végétale, F-84140 Montfavet, France; ${ }^{2}$ INRA, UR1052 Génétique et Amélioration des Fruits et \\ Légumes, F-84140 Montfavet, France; ${ }^{3}$ Department of Genetics and Biotechnology, Faculty of Agricultural Sciences, Aarhus \\ University, Denmark; ${ }^{4}$ UMR INRA-Agrocampus Ouest-Université de Rennes 1, Amélioration des Plantes et Biotechnologies \\ Végétales, Domaine de Kéraïber, F-29260 Ploudaniel, France; ${ }^{5}$ INRA-Agrocampus Ouest-Université Rennes 1, UMR1099 \\ BiO3P (Biology of Organisms and Populations applied to Plant Protection), F-35653 Le Rheu, France
}

Submitted 22 October 2010. Accepted 8 March 2011.

\begin{abstract}
The $N c_{\mathrm{tbr}}$ and $N y_{\mathrm{tbr}}$ genes in Solanum tuberosum determine hypersensitive reactions, characterized by necrotic reactions and restriction of the virus systemic movement, toward isolates belonging to clade $\mathrm{C}$ and clade $\mathrm{O}$ of Potato virus $\mathrm{Y}$ (PVY), respectively. We describe a new resistance from $S$. sparsipilum which possesses the same phenotype and specificity as $N c_{\text {tbr }}$ and is controlled by a dominant gene designated $N c_{\text {spl }} \cdot N c_{\text {spl }}$ maps on potato chromosome IV close or allelic to $N y_{\text {tbr. }}$ The helper component proteinase (HC-Pro) cistron of PVY was shown to control necrotic reactions and resistance elicitation in plants carrying $N c_{\text {spl }}, N c_{\text {tbr }}$, and $N y_{\text {tbr. }}$. However, inductions of necrosis and of resistance to the systemic virus movement in plants carrying $N c_{\text {spl }}$ reside in different regions of the HC-Pro cistron. Also, genomic determinants outside the HC-Pro cistron are involved in the systemic movement of PVY after induction of necroses on inoculated leaves of plants carrying $N y_{\text {tbr. }}$. These results suggest that the $N y_{\text {tbr }}$ resistance may have been involved in the recent emergence of PVY isolates with a recombination breakpoint near the junction of $\mathrm{HC}$-Pro and $\mathrm{P3}$ cistrons in potato crops. Therefore, this emergence could constitute one of the rare examples of resistance breakdown by a virus which was caused by recombination instead of by successive accumulation of nucleotide substitutions.
\end{abstract}

Potato virus $Y$ (PVY), the type member of the genus Potyvi$r u s$, is a major pathogen of potato and other solanaceous crops such as tobacco, tomato, and pepper (De Bokx and Huttinga 1981; Kerlan and Moury 2008). Control of PVY in potato

Corresponding author: B. Moury; Telephone: +33(0)4 327228 16; Fax: +33(0)4 327228 42; E-mail: Benoit.Moury@avignon.inra.fr

* The $e$-Xtra logo stands for "electronic extra" and indicates that a supplementary figure is published online.

This article is in the public domain and not copyrightable. It may be freely reprinted with customary crediting of the source. The American Phytopathological Society, 2011. crops is particularly difficult because the virus is efficiently transmitted both horizontally and vertically. Horizontal transmission of PVY from plant to plant can be achieved by more than 40 aphid species in a nonpersistent manner (Edwardson and Christie 1997; Ragsdale et al. 2001). Vertical transmission from PVY-infected plants to their progeny through tubers is a major problem for the sanitary selection of commercial seed potato tubers. Consequently, growing genetically resistant potato cultivars is one of the most efficient, environmentalfriendly, and target-specific methods to control PVY.

Different resistance genes to PVY, showing different specificities and phenotypes, have been characterized in potato and related species (Table 1). The species PVY can be divided into the three major clades: C, N, and O (Moury 2010). Clade C can be further divided into two subclades: $\mathrm{C} 1$ and $\mathrm{C} 2$ (BlancoUrgoiti et al. 1998a). Almost all potato isolates belong to clades $\mathrm{C} 2, \mathrm{~N}$, and $\mathrm{O}$, whereas isolates from clade $\mathrm{C} 1$ are found in other solanaceous crops such as pepper and tobacco (Moury 2010). In addition, several recombinant isolates, especially between clades $\mathrm{N}$ and $\mathrm{O}$, have been characterized (Glais et al. 2002; Revers et al. 1996; Schubert et al. 2007). The interactions between the resistance genes and PVY clades are summarized in Table 1.

Identification of avirulence genes is crucial to understand how viruses interact with major resistance genes. Variation in, and evolution capacity of the avirulence genes provide information about the resistance mechanism, specificity and durability (Bendahmane et al. 1995, 1999; Chowda-Reddy et al. 2011; Harrison 2002; Janzac et al. 2009, 2010; Mestre et al. 2000). In the potato-PVY interaction, only the avirulence factor corresponding to the $R y_{\text {sto }}$ gene was mapped and found to correspond to the NIa protease cistron of PVY (Mestre et al. 2000) (Table 1). The aim of our study was to map a new PVY resistance gene identified in the wild potato species Solanum sparsipilum and to characterize the corresponding PVY avirulence factor. It turned out that knowledge of the location of these factors in the potato and PVY genomes allowed understanding mechanisms of other potato-PVY genetic interactions and provided explanations for the recent emergence of recombinant PVY populations in potato crops. 


\section{RESULTS}

A new resistance in $S$. sparsipilum triggers hypersensitivity to PVY isolates from clade $\mathrm{C}$.

A PVY resistance associated with a hypersensitive response was found in $S$. sparsipilum genotype spl329.18. To characterize the specificity of the resistance, spl329.18 plants were challenged with isolate N605 representing clade N, O139 representing clade $\mathrm{O}$, and isolates SON41p and C-Scotland representing subgroups $\mathrm{C} 1$ and $\mathrm{C} 2$ of clade $\mathrm{C}$, respectively. The plants were inspected for symptoms on inoculated leaves and noninoculated apical leaves. In addition, the presence of PVY coat protein was determined in noninoculated apical leaves by double-antibody sandwich enzyme-linked immunosorbent assay (DAS-ELISA) (Moury et al. 2004). Manual inoculation of sp1329.18 with N605 and O139 did not induce any response on inoculated leaves but mosaic symptoms developed on noninoculated apical leaves and infection was confirmed by DASELISA (Table 2). By contrast, leaves inoculated with SON41p and C-Scotland displayed necrotic lesions 5 to 8 days postinoculation (dpi) whereas noninoculated apical leaves remained symptomless and negative in DAS-ELISA. Therefore, the resistance in $S$. sparsipilum genotype spl329.18 was specific to PVY isolates belonging to clade $C$ and characterized by a hypersensitive response in inoculated leaves. Moreover, the resistance response prevented the spread of these PVY isolates to noninoculated apical leaves. The pattern of responses observed in spl329.18 toward these PVY isolates was similar to that observed in King Edward, which is a reference $S$. tuberosum cultivar carrying the $N c_{\mathrm{tbr}}$ gene (Jones 1990) (Table 2).

\section{PVY resistance in $S$. sparsipilum is controlled by a single locus.}

To determine whether independent or linked genes controlled resistance to SON41p and C-Scotland, infectivity was analyzed on $\mathrm{F}_{1}$ hybrid clones from a cross between $S$. sparsipilum spl1329.18 and the dihaploid S. tuberosum genotype Caspar H3 (Caromel et al. 2005). Whereas S. sparsipilum was resistant to SON41p and C-Scotland, representing the $\mathrm{C} 1$ and $\mathrm{C} 2$ groups of PVY clade C, Caspar H3 was susceptible to SON41p and C-Scotland as well as to PVY isolates N605 and O139, representing clades $\mathrm{N}$ and $\mathrm{O}$, respectively (Table 2). Leaves of Caspar $\mathrm{H} 3$ inoculated with any of these four isolates did not display any resistance reaction and infection by all four isolates was confirmed in noninoculated apical leaves by DASELISA. Isolates C-Scotland, N605, and O139 also gave rise to mosaic symptoms in noninoculated apical leaves whereas infection by SON41p was not associated with visible symptoms. It should be noted that no virus infection could be evidenced by DAS-ELISA in noninoculated apical leaves of approximately half of the Caspar $\mathrm{H} 3$ plants that were inoculated with SON41p, which is an isolate adapted to pepper (Moury 2010) (Table 2). If the same or tightly linked genes determined resistance to SON41p and C-Scotland, it would be expected that $F_{1}$ hybrid clones would be either resistant to both SON41p and CScotland or susceptible to both. If resistances are unlinked, some clones will show a mixed response.

Resistance to SON41p and C-Scotland was evaluated on $189 \mathrm{~F}_{1}$ hybrid clones. The presence or absence of necrotic reactions was scored on manually inoculated detached leaves kept at high humidity and on greenhouse-grown plants. In addition, noninoculated apical leaves of greenhouse-grown plants were inspected for symptoms and tested for the presence of virus coat protein by DAS-ELISA. SON41p and CScotland induced necrotic local lesions on the inoculated leaves of 90 of the clones in both whole plants and detachedleaf assays. However, lesions were larger and appeared earlier on detached leaves. No symptoms were observed on the noninoculated apical leaves of these clones and PVY coat protein could not be detected by DAS-ELISA. The remaining 99 clones showed no local lesions in leaves inoculated with the SON41p or C-Scotland isolates, whatever the inoculation protocol (whole plant or detached leaves). All plants of these 99 clones inoculated with C-Scotland displayed positive DASELISA whereas only $47 \%$ of the plants inoculated with SON41p were identified as positive by DAS-ELISA, and absorbance values were highly variable from plant to plant (data not shown). This infection rate was comparable with SON41p infection in

Table 1. Potato virus Y (PVY) resistance genes in Solanum spp. ${ }^{\text {a }}$

\begin{tabular}{|c|c|c|c|c|c|}
\hline Gene & Response $^{\text {b }}$ & Origin & Spectrum of resistance & Chromosome & Reference \\
\hline$N c_{\text {spl }}$ & HR & Solanum sparsipilum & C clade & IV & This study \\
\hline$N c_{\mathrm{tbr}}$ & HR & S. tuberosum & C clade & ND & Cadman 1942; Cockerham 1970; Jones 1990 \\
\hline$N y-1$ & HR & S. tuberosum & ND & IX & Szajko et al. 2008; data not shown \\
\hline$N y_{\text {tbr }}$ & HR & S. tuberosum & O clade & IV & Celebi-Toprak et al. 2002; Cockerham 1970; Jones 1990 \\
\hline$R y_{\text {adg }}$ & ER & S. tuberosum subsp. andigena & All isolates & $\mathrm{XI}$ & Hämäläinen et al. 1997; Ross 1986 \\
\hline$R y_{\text {chc }}$ & ER & S. chacoense & All isolates & IX & Asama et al. 1982; Sato et al. 2006 \\
\hline$R y_{\text {sto }}$ & ER & S. stoloniferum & All isolates & XII & $\begin{array}{l}\text { Cockerham 1943; Flis et al. 2005; Song et al. 2005; } \\
\text { Valkonen et al. } 2008\end{array}$ \\
\hline
\end{tabular}

${ }^{\text {a }} \mathrm{ND}=$ not determined

${ }^{\mathrm{b}} \mathrm{ER}=$ extreme resistance and $\mathrm{HR}=$ hypersensitive reaction.

Table 2. Pathogenicity of Potato virus Y (PVY) isolates toward three Solanum spp. genotypes ${ }^{\mathrm{a}}$

\begin{tabular}{|c|c|c|c|c|c|c|c|c|c|c|}
\hline \multirow{2}{*}{\multicolumn{2}{|c|}{ PVY inoculum }} & \multicolumn{3}{|c|}{ Solanum sparsipilum spl329.18 } & \multicolumn{3}{|c|}{ S. tuberosum King Edward } & \multicolumn{3}{|c|}{ S. tuberosum Caspar $\mathrm{H3}$} \\
\hline & & \multirow{2}{*}{$\begin{array}{c}\text { Inoculated }^{\mathrm{b}} \\
\text { Symptoms }\end{array}$} & \multicolumn{2}{|c|}{ Noninoculated $^{c}$} & \multirow{2}{*}{$\begin{array}{c}\text { Inoculated }^{\text {b }} \\
\text { Symptoms }\end{array}$} & \multicolumn{2}{|c|}{ Noninoculated $^{\mathrm{c}}$} & \multirow{2}{*}{$\begin{array}{c}\text { Inoculated }^{\text {b }} \\
\text { Symptoms }\end{array}$} & \multicolumn{2}{|c|}{ Noninoculated $^{c}$} \\
\hline Isolate & Clade & & Symptoms & ELISA $^{d}$ & & Symptoms & ELISA $^{d}$ & & Symptoms & ELISA $^{d}$ \\
\hline N605 & $\mathrm{N}$ & $\varnothing$ & $\mathrm{mMO}$ & $24 / 24$ & $\varnothing$ & $\mathrm{mMO}$ & $20 / 20$ & $\varnothing$ & $\mathrm{mMO}$ & $20 / 20$ \\
\hline O139 & $\mathrm{O}$ & $\varnothing$ & MO & $20 / 20$ & $\varnothing$ & MO & $20 / 20$ & $\varnothing$ & MO & $20 / 20$ \\
\hline SON41p & $\mathrm{C} 1$ & HR & $\varnothing$ & $0 / 24$ & HR & $\varnothing$ & $0 / 21$ & $\varnothing$ & $\varnothing$ & $11 / 20$ \\
\hline C-Scotland & $\mathrm{C} 2$ & HR & 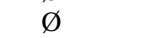 & $0 / 20$ & HR & $\varnothing$ & $0 / 20$ & $\varnothing$ & $\varnothing / \mathrm{mMO}$ & $20 / 20$ \\
\hline
\end{tabular}

${ }^{\mathrm{a}} \mathrm{HR}=$ necrotic reactions observed in inoculated leaves, $\mathrm{mMO}$ or MO $=$ mild or severe mosaic in noninoculated apical leaves, and $\varnothing=$ no symptoms

b Symptoms observed in inoculated leaves until 1 month postinoculation (mpi).

c Symptoms observed in apical, noninoculated leaves until $1 \mathrm{mpi}$.

d Evidence of infection according to double-antibody sandwich enzyme-linked immunosorbent assays (DAS-ELISAs) performed 1 mpi (number of plants positive in DAS-ELISA/total number of inoculated plants). 
the parental line Caspar H3 (Table 2). For all 99 clones, at least one of the plants inoculated with SON41p was positive by DASELISA. The perfect correlation in resistance and susceptibility reactions expressed after inoculation of the $F_{1}$ hybrid clones by PVY isolates SON41p and C-Scotland suggests that the same or tightly linked resistance genes were effective against the isolates representing the subgroups $\mathrm{C} 1$ and $\mathrm{C} 2$ of clade $\mathrm{C}$ in $S$. sparsipilum spl329.18. The 90:99 resistance/susceptibility segregation ratio observed among the Caspar $\mathrm{H} 3 \times$ spl329.18 progeny agreed well with a $1: 1$ ratio $\left(P\right.$ value $=0.61 ; \chi^{2}$ test $)$.

\section{The resistance to PVY clade C isolates}

in S. sparsipilum is dominant and maps to chromosome IV.

A 1:1 segregation ratio between resistant and susceptible clones in an $F_{1}$ progeny issued from a cross between two diploid potato genotypes fits with a monogenic resistance, either recessive or dominant. This would involve either that i) spl329.18 carries a dominant resistance gene in a heterozygous state while Caspar H3 does not carry this gene or that ii) spl329.18 carries a recessive resistance gene in a homozygous state while Caspar H3 is heterozygous at this locus and carries one copy of the recessive resistance gene. To map the resistance locus, we used the framework maps of Caspar H3 and spl329.18 built following the double pseudo-test cross strategy (Grattapaglia and Sederoff 1994) and described previously
(Caromel et al. 2005). Qualitative resistance data obtained on the $189 \mathrm{~F}_{1}$ hybrid clones classified as resistant or susceptible allowed mapping the locus controlling resistance to PVY clade $\mathrm{C}$ isolates on the framework map of spl329.18 using the software MapMaker. This locus mapped on chromosome IV, 3.5 centimorgans $(\mathrm{cM})$ distant from the amplified fragment length polymorphism marker E45M60_38 (Fig. 1A). The $N y_{\text {tbr }}$ gene from $S$. tuberosum, which confers resistance to PVY isolates belonging to clade $\mathrm{O}$, was also located on potato chromosome $\mathrm{IV}$, at a maximum distance of $3.4 \mathrm{cM}$ from the restriction fragment length polymorphism (RFLP) marker TG506 (CelebiToprak et al. 2002) (Table 1; Fig. 1). TG506 was developed as a cleaved amplified polymorphic sequence (CAPS) marker for S. bulbocastanum by Park and associates (2005) and the endonuclease HindIII revealed a polymorphism between spl329.18 and Caspar H3. The TG506-derived CAPS cosegregated with PVY resistance on the 189 potato clones (Fig. 1A). Only genes or markers in a heterozygous state can be located on a parental map using data from an $\mathrm{F}_{1}$ hybrid progeny (Grattapaglia and Sederoff 1994). Consequently, because the PVY resistance gene was located on the framework map of spl329.18 but not on that of Caspar H3, this indicated that spl329.18 was heterozygous at the resistance locus and that the resistance gene was dominant, while Caspar H3 did not carry the resistance allele. To illustrate this, we examined the $43 \mathrm{~F}_{1}$ hybrid clones
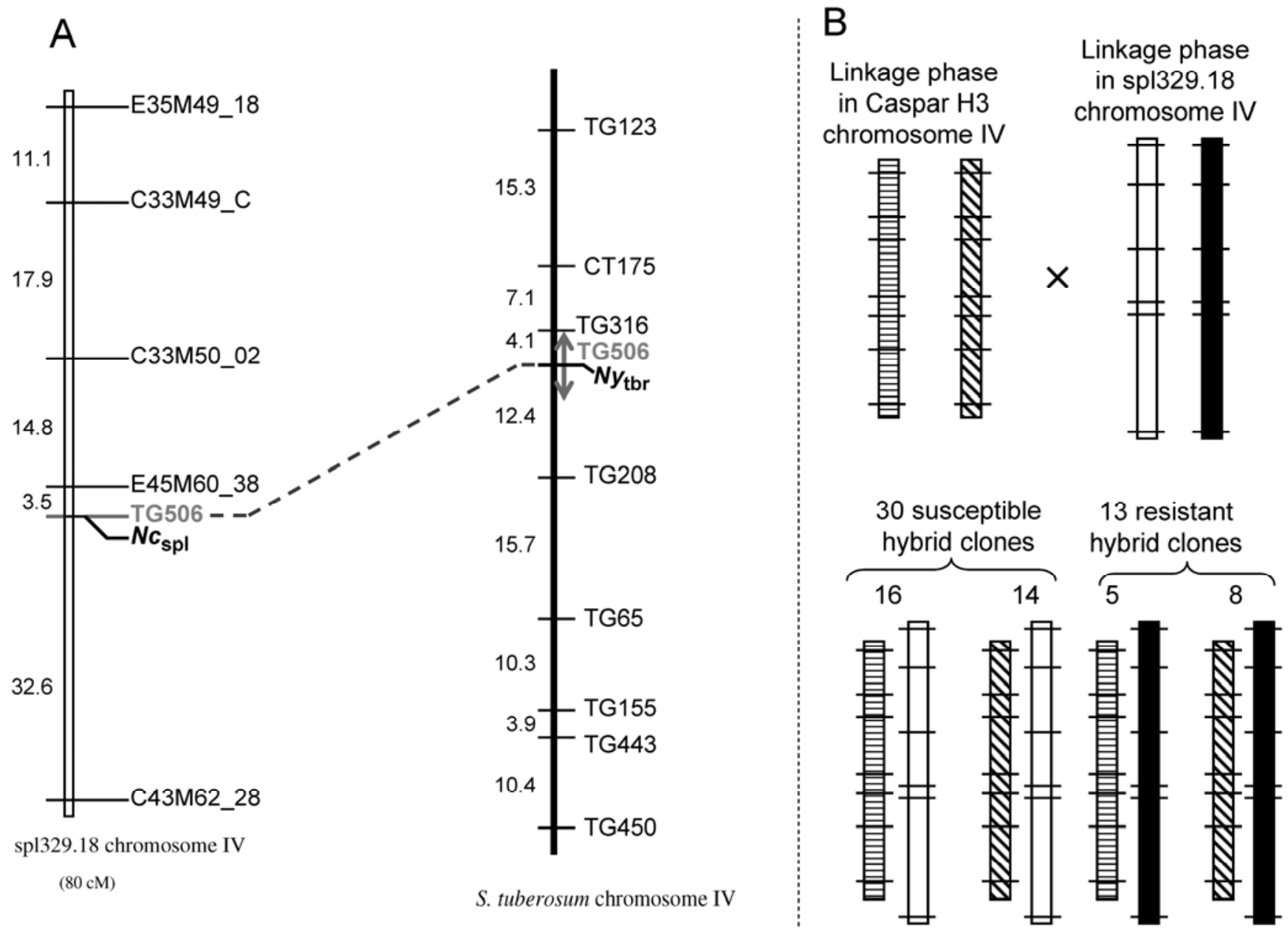

Fig. 1. Maps of chromosome IV of Solanum sparsipilum and S. tuberosum. A, Genetic map of chromosome IV of the S. sparsipilum clone spl329.18 and $S$. tuberosum (adapted from Celebi-Toprak et al. 2002), carrying the resistance genes $N c_{\text {sp } 1}$ and $N y_{\text {tbr }}$, respectively. $N c_{\text {spl }}$ and marker TG506 were located on the framework map of spl329.18 described by Caromel and associates (2005). On the $S$. tuberosum map, the restriction fragment length polymorphism marker TG506 is placed at logarithm of odds score $<3$ in an interval (in gray) of 3.4 centimorgans around $N y_{\text {tbr }}$ (Celebi-Toprak et al. 2002). B, Schematic maps of markers in chromosome IV of S. tuberosum Caspar H3 and S. sparsipilum spl329.18 parental clones and the $\mathrm{F}_{1}$ hybrid clones that did not show any evidence of recombination along chromosome IV. 
that did not show any evidence for recombination in chromosome IV. In all, 30 of these clones were susceptible to PVY while 13 were resistant. All 30 susceptible clones shared the same linkage phase in spl329.18 while all 13 resistant clones possessed the opposite linkage phase in spl329.18 (Fig. 1B). In contrast, the two linkage phases in Caspar H3 were observed among the susceptible and the resistant clones. This indicated that, at the locus involved in resistance, one allele from spl329.18 was systematically associated with PVY resistance and the other one with susceptibility whereas there was no particular association between any of the corresponding alleles of Caspar $\mathrm{H} 3$ and the resistance response. These results showed that resistance to PVY isolates of clade $\mathrm{C}$ in spl329.18 was monogenic and dominant. For simplicity, we will consider in the following that a single locus, named $N c_{\text {spl }}$, controls the resistance of spl329.18 to the two PVY isolates of clade $\mathrm{C}$.

\section{The helper component proteinase cistron of PVY isolates from clade $C$ determines avirulence toward the $N c_{\text {spl }}$ and $N c_{\text {tbr }}$ resistance genes.}

The resistance responses in spl239.18 and King Edward were characterized by development of necrotic local lesions on inoculated leaves and a resistance response preventing infection of noninoculated apical leaves. This response is typical of hypersensitive reactions (HR) induced by dominant resistance genes; therefore, we wanted to identify viral elicitors of $\mathrm{HR}$ and avirulence genes corresponding to the resistances. Because infectious cDNA clones were available for the virulent PVY isolate N605 belonging to clade $\mathrm{N}$ and for the avirulent isolate SON41p belonging to the $\mathrm{C} 1$ subgroup of clade C (Bukovinszki et al. 2007; Jakab et al. 1997; Moury et al. 2004), we generated chimeras between these clones to map the avirulence genes corresponding to the $N c$ resistances.

Initially, four chimeras (numbers 1 to 4 ) were analyzed by inoculation of detached leaves of $S$. sparsipilum spl239.18 (Fig. 2A; Table 3). Only chimera number 3 induced necrotic lesions on leaves, which designated the region encoding helper component proteinase (HC-Pro), a few codons of P3, or a small part of the CI cistron as candidates for the avirulence factor. Among these three regions, the HC-Pro cistron presented the largest number of synonymous and nonsynonymous nucleotide differences between the virulent and avirulent isolates (data not shown). Therefore, to test whether the HC-Pro cistron of SON41p contained the avirulence factor toward $N c_{\text {spl }}$, we created chimeras 5 and 6 , wherein the HC-Pro cistron alone was exchanged between the two cDNA clones (Fig. 2B). These chimeras were inoculated to $S$. sparsipilum spl239.18 carrying $N c_{\text {spl }}$, S. tuberosum King Edward carrying $N c_{\text {tbr }}$ and Nicotiana clevelandii. Chimera number 5 showed pathogenicity properties similar to SON41p on spl329.18 and S. tuberosum King Edward, with necrosis on inoculated leaves and absence of detectable virus in noninoculated apical leaves (Table 3 ). The reciprocal chimera number 6 did not induce local lesions on spl329.18 and King Edward, and PVY coat protein was detected by DAS-ELISA in noninoculated apical leaves. Although both chimeras were fully infectious in $N$. clevelandii, infecting $100 \%$ of inoculated plants and showing no obvious infectivity defect, chimera number 6 infected only a proportion of the $S$. sparsipilum spl239.18 (12 of 24) and S. tuberosum King Edward (5 of 24) plants. This partial infectivity, similar to that of the parental virus SON41p on S. tuberosum Caspar H3 (Table 2 ), could be due to the fact that the genome of chimera number 6 is derived mostly from SON41p, which is a PVY isolate adapted to pepper but poorly adapted to potato. Altogether, these results indicated that the elicitor of necrotic lesions in inoculated leaves and the avirulence factor inducing a resis- tance response preventing virus spread in noninoculated apical leaves in both $S$. sparsipilum spl329.18 carrying $N c_{\text {spl }}$ and $S$. tuberosum King Edward carrying $N c_{\text {tbr }}$ were located in the HCPro cistron of PVY isolate SON41p.

\section{Induction of necrotic local lesions and resistance to the systemic virus spread depend on different regions of the HC-Pro cistron.}

To get further in the delimitation of the region involved in PVY avirulence toward the $N c$ resistances, additional viral chimeras and mutants were built and analyzed. In chimera number 7, the region encompassing nucleotides 2,017 to 2,409 (codons 335 to 465 of the HC-Pro cistron) of N605 was exchanged by the corresponding region of SON41p. After inoculation of $S$. sparsipilum spl239.18, chimera number 7 induced necrotic lesions on inoculated leaves and, 3 weeks postinoculation, necrotic lesions also appeared on noninoculated apical leaves, and accumulation of virus in these leaves was confirmed by DAS-ELISA. Therefore, compared with chimera 5, chimera 7 had lost the ability to induce resistance to systemic spread, while it retained the region necessary to induce necrosis (Table 3). In contrast, chimera 7 infected 100\% of the susceptible $S$. tuberosum Caspar H3 or Safrane (16 of 16 inoculated plants for each genotype) at the systemic level without inducing any necrotic reactions in inoculated or apical leaves. These infections were symptomless in Safrane and caused mild mosaics in Caspar H3 (data not shown). This indicated that the region inducing necrosis could be separated from the region necessary for expression of the resistance to PVY systemic spread of $S$. sparsipilum spl239.18, carrying $N c_{\text {spl. }}$. In other words, we could consider this mixed phenotype as an incomplete breakdown of the $N c_{\text {spl }}$ resistance, where the $\mathrm{HR}$ is induced but the plant resistance response is not efficient enough to contain the virus in the inoculated leaves.

\section{Induction of necrosis in $S$. sparsipilum carrying $N c_{\mathrm{spl}}$ is determined by an 89-nucleotide-long sequence in the HC-Pro cistron of isolate SON41p.}

To investigate the region inducing necrosis, the predicted amino acid sequences corresponding to codons 335 to 465 of the HC-Pro cistron of N605, SON41p, and other PVY isolates belonging to clades $\mathrm{N}, \mathrm{O}$, and $\mathrm{C}$ available in databanks were aligned. In this region, we identified seven nonsynonymous differences between SON41p and N605, at codon positions 339, 347, 350, 355, 363, 400, and 419 (Fig. 3). However, only the polymorphism at codon 363 distinguished the PVY clades in accordance to their specificity of interaction with the $\mathrm{Nc}$ resistances. At this position, an isoleucine codon was found in all isolates of clades $\mathrm{N}$ and $\mathrm{O}$, while isolates from clade $\mathrm{C}$ possessed a valine codon (Fig. 3). At the other variable codons, most of the isolates belonging to clade $\mathrm{C}$ were identical to isolates belonging to clade $\mathrm{O}$, and these codons were consequently presumed to be less likely to explain the difference in response of plants carrying the $N c$ genes. This suggested that codon position 363 could play a role in determining HR elicitation in potato plants carrying $N c$ resistances. To validate this assumption and map more precisely the region involved in HR elicitation, we constructed three other chimeras: i) chimera number 8 , in which the isoleucine codon at position 363 of N605 HC-Pro cistron was changed to a valine codon (corresponding to an $\mathrm{A}_{2101} \mathrm{G}$ nucleotide substitution in the N605 genome); ii) chimera number 9 , in which the region encompassing codons 335 to 364 of N605 HC-Pro cistron, corresponding to nucleotides 2,017 to 2,105 in N605 genome, were exchanged by the corresponding region from SON41p; and iii) chimera number 10, in which codons at positions 357 to 465 of N605 HC-Pro cistron (nucleotides 2,085 to 2,409 in N605 genome) 


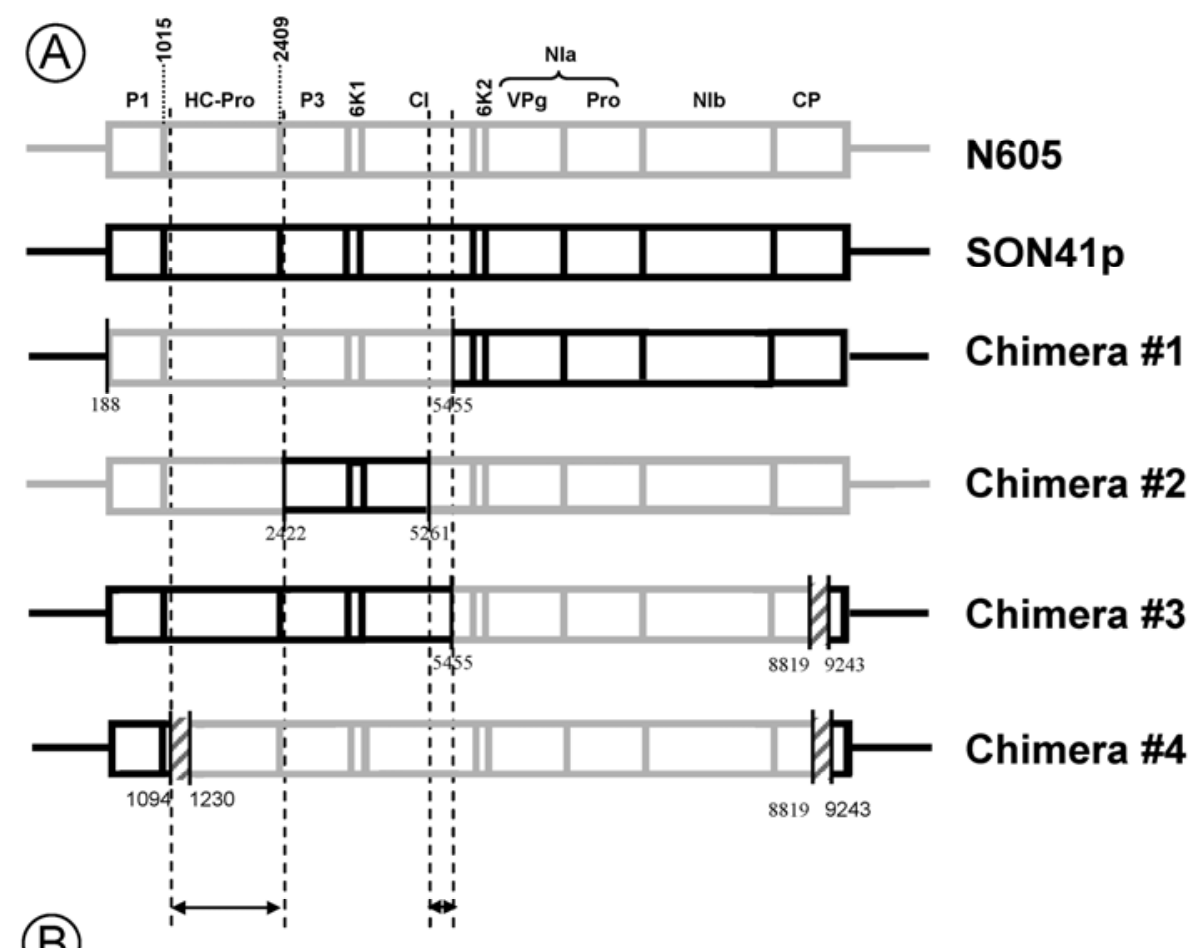

(B)

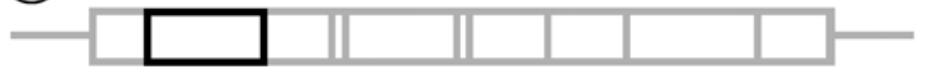

Chimera \#5

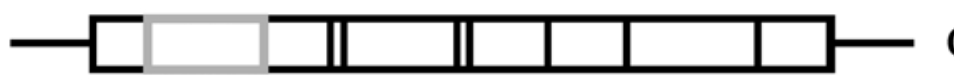

Chimera \#6

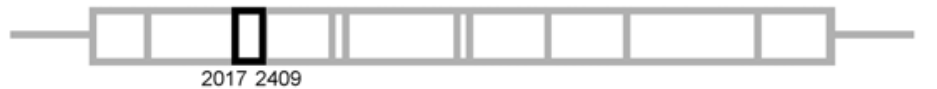

Chimera \#7

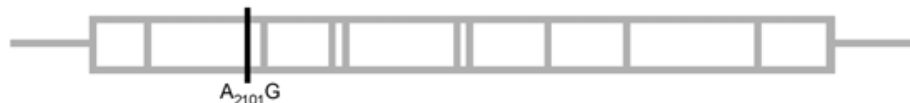

Chimera \#8

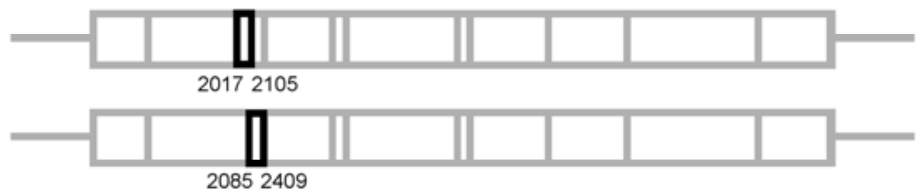

Chimera \#9

Chimera \#10

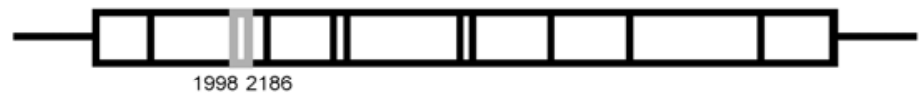

Chimera \#11

(C)

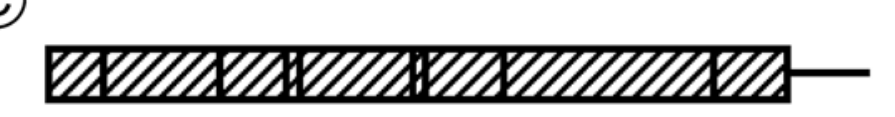

PVY O (isolates

O-Scotland and

0-139)

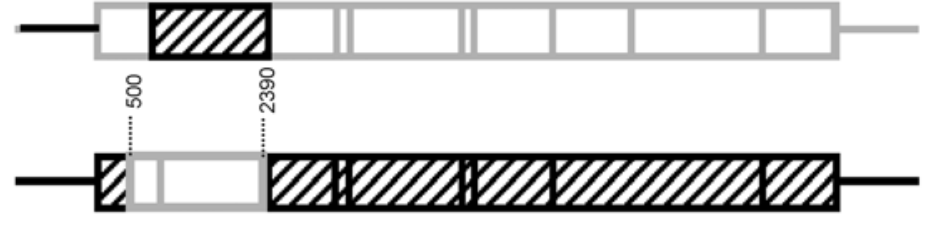

Chimeras \#12 and \#13

PVY N-Wilga (isolates Isol5 and LW)

Fig. 2. Maps of Potato virus $Y$ (PVY) isolates, recombinant PVY cDNA clones, and natural recombinant isolates. A, N605 (gray) and SON41p (black) parental PVY cDNA clones and chimeras between them with the genome regions corresponding to N605 in gray and the genome regions corresponding to SON41p in black. Hatched zones identify regions where the recombination sites were not precisely determined but delimited by endonuclease restriction sites. Arrows at the bottom show the location of the candidate regions for avirulence toward Nc. B, Helper component proteinase (HC-Pro) chimeras between SON41p and N605. C, HC-Pro chimeras and natural recombinant isolates between clade O (hatched) and clade N (gray) isolates (Schubert et al. 2007). Chimeras were obtained by recombination between the N605 cDNA clone and cDNAs corresponding to the HC-Pro cistrons of isolates O139 or O-Scotland. Accession numbers are X97895 (N605), AJ439544 (SON41p), U09509 (O139), AY691546 (O-Scotland), AJ890350 (Isol5), and AJ890349 (LW). Nucleotide positions are based on the sequence of the genome of N605. 
were exchanged by the corresponding region from SON41p (Fig. 2B). On S. sparsipilum spl239.18, chimeras 8 and 10 induced a response identical to N605, without symptoms on inoculated leaves but with mild mosaics on noninoculated apical leaves and positive DAS-ELISA in all plants (Table 3). In contrast, chimera number 9 induced necrotic lesions on inoculated leaves and a severe systemic necrosis on noninoculated apical leaves, which led to plant death 1 month postinoculation (Supplementary Fig. S1). Chimera number 9 behaved like chimera number 7 in inoculated Caspar H3 or Safrane plants (16 of 16 systemic infections for each $S$. tuberosum genotype) with- out showing any necrotic reaction in inoculated or apical leaves. These results demonstrated that necrosis was induced if the virus carried only 89 nucleotides of SON41p corresponding to codons 335 to 364 of the HC-Pro cistron. This was further supported by inoculation with chimera number 11, in which codons 328 to 391 of the HC-Pro cistron of SON41p (corresponding to nucleotide positions 1,998 to 2,186 in the N605 genome) were replaced with the corresponding region from N605 (Fig. 2B). Chimera number 11 did not induce necrosis on inoculated leaves of $S$. sparsipilum, symptoms were not observed on noninoculated apical leaves, and the virus was not

Table 3. Pathogenicity of Potato virus Y (PVY) isolates N605 and SON41p and chimeras in Solanum sparsipilum spl239.18 and S. tuberosum King Edward carrying the $N c_{\mathrm{spl}}$ and $N c_{\mathrm{tbr}}$ resistance genes, respectively ${ }^{\mathrm{a}}$

\begin{tabular}{|c|c|c|c|c|c|c|}
\hline \multirow[b]{3}{*}{ PVY variant } & \multicolumn{3}{|c|}{ S. sparsipilum spl329.18 } & \multicolumn{3}{|c|}{ S. tuberosum King Edward } \\
\hline & \multirow{2}{*}{$\frac{\text { Inoculated }^{\text {b }}}{\text { Symptoms }}$} & \multicolumn{2}{|c|}{ Noninoculated apical $^{\mathrm{c}}$} & \multirow{2}{*}{$\begin{array}{l}\text { Inoculated }^{\mathrm{a}} \\
\text { Symptoms }\end{array}$} & \multicolumn{2}{|c|}{ Noninoculated apical $^{\mathrm{c}}$} \\
\hline & & Symptoms & DAS-ELISA $^{d}$ & & Symptoms & DAS-ELISA $^{\mathrm{d}}$ \\
\hline N605 & $\varnothing$ & $\mathrm{mMO}$ & $24 / 24$ & $\varnothing$ & $\mathrm{mMO}$ & $20 / 20$ \\
\hline SON41p & HR & $\varnothing$ & $0 / 24$ & HR & $\varnothing$ & $0 / 21$ \\
\hline \multicolumn{7}{|l|}{ Chimera } \\
\hline 1 & $\varnothing$ & - & - & - & - & - \\
\hline 2 & $\varnothing$ & - & - & - & - & - \\
\hline 3 & HR & - & - & - & - & - \\
\hline 4 & $\varnothing$ & - & - & - & - & - \\
\hline 5 & HR & $\varnothing$ & $0 / 24$ & HR & $\varnothing$ & $0 / 23$ \\
\hline 6 & $\varnothing$ & $\varnothing$ & $12 / 24$ & $\varnothing$ & $\varnothing$ & $5 / 24$ \\
\hline 7 & HR & SHR & $20 / 20$ & - & - & - \\
\hline 8 & $\varnothing$ & $\mathrm{mMO}$ & $20 / 20$ & - & - & - \\
\hline 9 & HR & SHR & $20 / 20$ & - & - & - \\
\hline 10 & $\varnothing$ & $\mathrm{mMO}$ & $10 / 10$ & - & - & - \\
\hline 11 & $\varnothing$ & $\varnothing$ & $0 / 20$ & - & - & - \\
\hline
\end{tabular}

${ }^{\mathrm{a}} \mathrm{HR}=$ necrotic reactions observed in inoculated leaves, $\mathrm{SHR}=$ necrosis in noninoculated apical leaves, $\mathrm{mMO}$ or MO = mild mosaic or severe mosaic in noninoculated apical leaves, $\varnothing=$ no symptoms, and $-=$ not tested.

${ }^{\mathrm{b}}$ Symptoms observed in inoculated leaves until 1 month postinoculation (mpi).

${ }^{\mathrm{c}}$ Symptoms observed in apical, noninoculated leaves until $1 \mathrm{mpi}$.

${ }^{\mathrm{d}}$ Evidence of infection according to double-antibody sandwich enzyme-linked immunosorbent assays (DAS-ELISAs) performed one mpi (number of plants positive in DAS-ELISA/total number of inoculated plants).

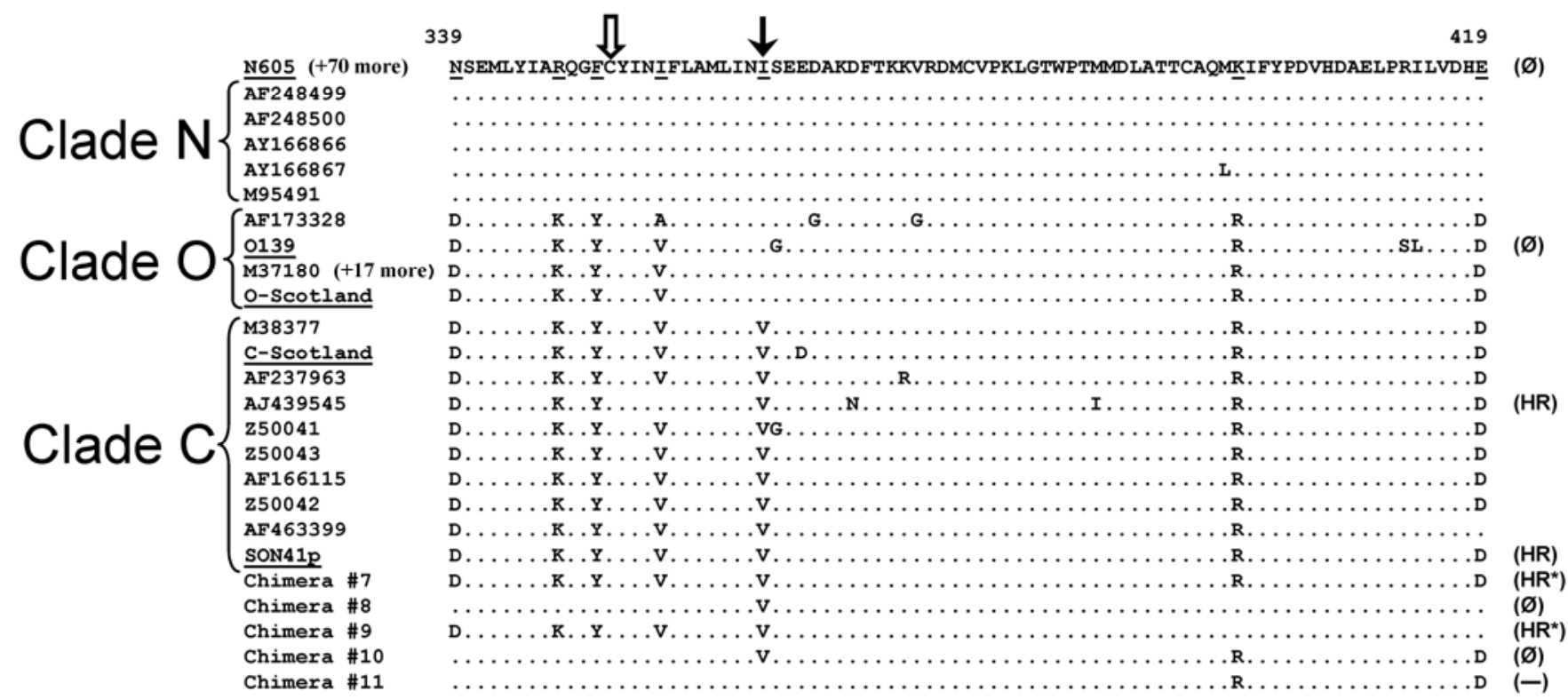

Fig. 3. Amino acid alignment of the $\mathrm{C}$ terminal part (amino acids 339 to 419) of the helper component proteinase (HC-Pro) of isolates belonging to the three major Potato virus Y (PVY) clades. Seven amino acid differences between SON41p (accession no AJ439544) and N605 (X97895) are underlined. Sequences of O-Scotland (accession no AY691546), O139 (U09509), and C-Scotland (AF227515) isolates used in our experiments are indicated. In all, 70 more PVY isolates from the $\mathrm{N}$ clade were identical to $\mathrm{N} 605$ at these seven amino acid positions and 15 more from the $\mathrm{O}$ clade were identical to accession number M37180 (data not shown). Black arrow indicates the only position where amino acid polymorphism corresponds to virulence properties toward the $N c$ gene. White arrow indicates the cysteine residue at position 351, which is part of the protease active site of the HC-Pro of Tobacco etch virus (Oh and Carrington 1989) and is conserved among all members of the genus Potyvirus. The behavior of some PVY isolates or chimeras toward the $N c_{\text {spl }}$ resistance is indicated in parentheses: $\mathrm{HR}=$ induction of local necrotic reactions and resistance to infection at the systemic level, HR* $=$ induction of necrotic reactions at the local and systemic levels, $\varnothing=$ systemic infection with no visible local reactions, and $-=$ no systemic infection and no visible local reactions. 
detected by DAS-ELISA in any of the plants. Chimera number 11 was fully infectious in the susceptible control $S$. tuberosum Safrane and partially infectious in Caspar H3, causing symptomless systemic infections in 15 of 15 or in 5 of 16 inoculated plants, respectively (data not shown). This low infectivity level in Caspar H3 could be due to the fact that, like SON41p, with which it shares most of its genome, chimera number 11 is poorly adapted to $S$. tuberosum (Table 2). Nevertheless, this showed that chimera number 11 was targeted by resistance in S. sparsipilum spl239.18 but had lost the capacity to induce the necrotic lesions observed in leaves inoculated with SON41p. This phenotypic reaction is similar to extreme resistance and could be due to the fact that chimera number 11 is more efficiently contained by the resistance of spl239.18 than SON41p.

\section{The HC-Pro cistron of PVY isolates from clade $O$ induces necrotic reactions and resistance in potato plants carrying the $N \boldsymbol{y}_{\text {tbr }}$ gene.}

Because $N c_{\text {spl }}$ and $N y_{\text {tbr }}$ are located closely on potato chromosome IV (and could even be alleles of the same gene), they could derive from the same ancestral gene and, therefore, could recognize the same target in the PVY genome. To test this assumption, we built two chimeras, numbers 12 and 13 (Fig. 2C), where the HC-Pro cistron of N605 was substituted by the homologous genome region of either the O-Scotland or O139 isolates of clade O. N605 did not induce any HR in inoculated leaves of $S$. tuberosum cvs. Désirée and Pentland Crown, two reference genotypes carrying the $N y_{\mathrm{tbr}}$ gene, and was able to infect these genotypes at the systemic level, as attested by ELISA results (Table 4). By contrast, in inoculated leaves of these two potato cultivars, the O-Scotland and O139 isolates and chimeras 12 and 13 induced large necrotic local lesions, often followed by a complete necrosis of these leaves (Table 4). The O-Scotland and O139 isolates but not chimeras 12 and 13 were also able to induce necrotic lesions at the systemic level in a large proportion of these plants (Table 4), and virus was detected in these necrotic, noninoculated leaves by DAS-ELISA. These results demonstrate that the HC-Pro cistron of PVY clade O isolates is an elicitor of the necrotic reactions and an avirulence factor of the resistance controlled by the $N y_{\mathrm{tbr}}$ gene. The difference in behavior of the potato genotypes carrying $N y_{\mathrm{tbr}}$ after inoculation by the O-Scotland or O139 isolates from one side and by chimeras 12 or 13 from the other side also show that genome regions outside the HC-Pro cistron contribute to the systemic movement of the virus despite inducing similar necrotic reactions in inoculated leaves.

We could not exclude the possibility that other genome regions of PVY clade $\mathrm{O}$ isolates also act as elicitors of the re- sistance controlled by $N y_{\mathrm{tbr}}$. To do so, we would need to build a reciprocal chimera, where the HC-Pro cistron of a clade $\mathrm{N}$ $\mathrm{PVY}$ isolate is recombined within a PVY O genome. However, this was not possible because no infectious cDNA clone is available for clade O PVY isolates.

\section{DISCUSSION}

We have identified a resistance conferred by the $N c_{\text {spl }}$ gene in $S$. sparsipilum, which displayed the same phenotype, specificity, and avirulence factor as the resistance controlled by the $N c_{\text {tbr }}$ gene from $S$. tuberosum. This resistance was controlled by a dominant gene which mapped on potato chromosome IV. $N c_{\text {spl }}$ cosegregated with marker TG506, which is close to $N y_{\text {tbr }}$, a gene from $S$. tuberosum that confers necrotic reactions and resistance to clade O PVY isolates (Celebi-Toprak et al. 2002). In $S$. tuberosum, a maximum distance of $3.4 \mathrm{cM}$ between TG506 and $N y_{\text {tbr }}$ was estimated but TG506 was not mapped with a high precision (logarithm of odds score $<3$ ) (CelebiToprak et al. 2002). This suggested that $N c_{\text {spl }}$ and $N y_{\text {tbr }}$ are either closely linked genes or alleles of the same gene.

Our reverse-genetics approach demonstrated that the HCPro cistron is the avirulence factor corresponding to the $N c_{\text {spl }}$ and $N c_{\text {tbr }}$ resistance genes. Indeed, exchange of this region between the cDNA clones of an avirulent PVY isolate (SON41p) and a virulent one (N605) switched their virulence properties toward spl329.18 and King Edward carrying $N c_{\text {spl }}$ and $N c_{\text {tbr }}$, respectively. It should be noted that chimera number 6 showed an infectivity level in spl329.18 which is similar to that of its parental virus SON41p in the susceptible $S$. tuberosum genotype Caspar H3 (Tables 2 and 3), indicating that this "partial virulence" resulted from poor adaptation of SON41p to Solanum spp. (Moury 2010) rather than from the existence of undetermined virulence factors additional to the HC-Pro cistron in the PVY genome. For the first time, an avirulence factor corresponding to an HR-associated resistance in potato has been mapped in the PVY genome. The NIa protease cistron of PVY has previously been identified as the avirulence determinant in potato carrying the $R y_{\text {sto }}$ gene, which is associated with extreme resistance (Mestre et al. 2000).

Our results showed that the necrotic reactions and resistance per se (i.e., restriction of systemic invasion of the plant by the virus) controlled by $N c$ could operate independently and were activated by different regions of the HC-Pro cistron. A region corresponding to codons 335 to 364 of the HC-Pro cistron was sufficient for induction of necrotic reactions in the inoculated potato leaves but not for the sequestration of PVY in these leaves. This was illustrated by chimera number 9 , which induced local and systemic necrotic reactions and infected $S$. sparsipilum

Table 4. Pathogenicity of Potato virus Y (PVY) isolates N605, O139, and O-Scotland and chimeras in Solanum tuberosum cvs. Pentland Crown and Désirée carrying the $N y_{\text {tbr }}$ resistance gene ${ }^{\mathrm{a}}$

\begin{tabular}{|c|c|c|c|c|c|c|}
\hline \multirow[b]{3}{*}{ PVY variant } & \multicolumn{3}{|c|}{ S. tuberosum Désirée } & \multicolumn{3}{|c|}{ S. tuberosum Pentland Crown } \\
\hline & \multirow{2}{*}{$\begin{array}{c}\text { Inoculated }^{b} \\
\text { Symptoms }\end{array}$} & \multicolumn{2}{|c|}{ Noninoculated apical $^{\mathbf{c}}$} & \multirow{2}{*}{$\begin{array}{c}\text { Inoculated }^{\text {b }} \\
\text { Symptoms }\end{array}$} & \multicolumn{2}{|c|}{ Noninoculated apical $^{\mathrm{c}}$} \\
\hline & & Symptoms & DAS-ELISA $^{d}$ & & Symptoms & DAS-ELISA $^{d}$ \\
\hline N605 & $\varnothing$ & $\mathrm{mMO}$ & $10 / 10$ & $\varnothing$ & $\mathrm{mMO}$ & $10 / 10$ \\
\hline O139 & HR & SHR & $9 / 10$ & HR & SHR & $5 / 10$ \\
\hline O-Scotland & HR & SHR & $10 / 10$ & HR & SHR & $7 / 10$ \\
\hline Chimera 12 & HR & $\varnothing$ & $0 / 15$ & HR & $\varnothing$ & $0 / 15$ \\
\hline Chimera 13 & HR & $\varnothing$ & $0 / 15$ & HR & $\varnothing$ & $0 / 15$ \\
\hline
\end{tabular}

${ }^{\mathrm{a}} \mathrm{HR}=$ necrotic reactions observed in inoculated leaves, $\mathrm{SHR}=$ necrosis in noninoculated apical leaves, $\mathrm{mMO}$ or $\mathrm{MO}=$ mild mosaic or severe mosaic in noninoculated apical leaves, and $\varnothing=$ no symptoms.

${ }^{\mathrm{b}}$ Symptoms observed in inoculated leaves until 1 month postinoculation (mpi).

${ }^{c}$ Symptoms observed in apical, noninoculated leaves until 1 mpi.

d Evidence of infection according to double-antibody sandwich enzyme-linked immunosorbent assays (DAS-ELISA) performed one mpi (number of plants positive in DAS-ELISA/total number of inoculated plants). 
plants systemically. A first hypothesis to explain this phenomenon is the existence in the PVY HC-Pro cistron of two viral determinants of the phenotype of the $N c$ resistance: one determinant specific for the elicitation of the resistance and another, nonoverlapping determinant specific for the targeting of this induced resistance, as was recently demonstrated for other plant-virus pairs (Bhattacharjee et al. 2009). An alternative hypothesis is that the structural conformations of parental and chimeric HC-Pro cistrons or encoded proteins could display different affinities with their plant receptors and, therefore, could induce resistance responses more or less efficient to restrict the virus systemic movement. Codon positions 400 and 419 of the HC-Pro cistron of PVY were previously shown to determine veinal necroses at the systemic level in $N$. tabacum (Tribodet et al. 2005). These positions are located close to the region that we identified as the necrosis inducer in $N c$ potato genotypes (spanning codons 335 to 364 ). However, the two symptom determinants do not overlap in the PVY genome, because modifying codons 400 and 419 (chimera number 10) did not alter the PVY symptoms in $S$. sparsipilum (Table 3 ).

A remaining question is whether the $N c$ resistance elicitor is the viral RNA or the encoded protein. Both situations can occur in plant resistance-virus interactions, though few studies have discriminated between the two possibilities (Burch-Smith et al. 2007; Szittya and Burgyan 2001). Most virulence mutations in plant viruses are nonsynonymous substitutions (Harrison 2002; Janzac et al. 2009). In addition, positive selection is frequent in viral virulence factors (Moury et al. 2004; Schirmer et al. 2005) and a significant link was shown between the constraint acting on amino acid substitutions in proteins encoded by virulence factors and the durability of the corresponding plant resistances (Janzac et al. 2009). These results suggest that recognition of viral proteins by plant resistances is the rule and recognition of virus genome entities is the exception.

Under the assumption that amino acid differences in the HCPro are responsible for differences in elicitation of the necrotic reactions controlled by $N c$, it would be important to figure out which amino acids could play major roles in these reactions. Five amino acids at positions 339, 347, 350, 355, and 363 of the HC-Pro differ between N605 and chimera number 9, which induces necrotic reactions in Nc plants (Fig. 3). The comparison of sequences and phenotypes of SON41p (and other isolates from clade $\mathrm{C}$ ) and isolates from clade $\mathrm{O}$ (Fig. 3) highlight the importance of codon 363 in the induction of necrotic reactions in spl239.18. However, the $\mathrm{I}_{363} \mathrm{~V}$ amino acid substitution did not modify the virulence of the N605 isolate toward $N c$ (chimera number 8) (Fig. 3). This suggested that not only are the expression of the different traits associated with the $N c$ resistance phenotype (local necrosis and lack of infection at the systemic level) controlled by different regions of the HC-Pro cistron but also induction of the necrotic reactions depends both on codon 363 and on the context of the HC-Pro cistron. Also, among the five substitutions described above, the $\mathrm{I}_{355} \mathrm{~V}$ substitution is unlikely to be involved in induction of the necrotic reactions, because an isoleucine is present at this position in isolate LYE84.2 (accession number AJ439545) (Fig. 3) which is avirulent toward Nc and induces necrotic local lesions in spl329.18 and King Edward (data not shown).

Chimeras number 12 and 13 and their parental isolates (Fig. 2; Table 4) also illustrate the complex relationships between elicitation of necrotic reactions and avirulence in the PVYpotato system. Although the HC-Pro cistron of clade O PVY isolates is involved in elicitation of necrotic reactions and resistance in potato cultivars carrying the $N y_{\mathrm{tbr}}$ gene, variation in other parts of the PVY genome also contribute to systemic infection of these cultivars, as was shown for the clade $\mathrm{O}$ parental isolates O139 and O-Scotland (Table 4). Systemic infec- tions associated with local necrotic reactions are frequent in the $N y_{\mathrm{tbr}}$-carrying potato cultivars Désirée and Pentland Crown inoculated by clade O PVY isolates (Jones 1990).

HC-Pro is a multifunctional protein which is frequently involved in Potyvirus symptomatology (Sáenz et al. 2002; Shiboleth et al. 2007; Torres-Barcelo et al. 2008; Yambao et al. 2008) and in the suppression of plant defenses based on RNA silencing (Brigneti et al. 1998; Shiboleth et al. 2007; Varrelmann et al. 2007). It is also involved in aphid-mediated transmission, processing of the potyviral polyprotein, genome amplification, cell-to-cell movement, and translocation through the vascular system (Urcuqui-Inchima et al. 2001). More particularly, the HC-Pro cistron of Soybean mosaic virus (SMV), together with the P3 cistron, was shown to act as an avirulence factor toward the Rsvl resistance in soybean (Eggenberger et al. 2008). In contrast to the SMV-Rsvl system, the HC-Pro cistron alone was involved in the virulence or avirulence properties of PVY toward $N c$, as shown by the reciprocal chimeras 5 and 6 (Table 3 ).

By analogy with Tobacco etch virus (TEV), the $N c$ elicitor region in the HC-Pro of PVY may overlap with the active site of the protease domain. The cysteine at position 351 of the HC-Pro of TEV, which was shown to be part of the protease active site (Oh and Carrington 1989), is conserved at the same position of the HC-Pro of PVY (Fig. 3) and of most Potyvirus spp. (data not shown). Therefore, it is possible that alteration of the protease activity of PVY HC-Pro by amino acid substitutions in the vicinity of this cysteine residue (e.g., at positions 350 and 355, where the amino acids differed between N605 and SON41p) can affect the elicitation of the $N c$ resistance, similarly to the scenario proposed for the elicitation of the $R y_{\text {sto }}$ resistance in potato by the NIa protease of PVY (Mestre et al. 2003).

The identification of the avirulence factors corresponding to $N c_{\text {tbr }}$ and $N y_{\text {tbr }}$ could help explain changes in the prevalence of the PVY isolates belonging to the different clades and emergence of particular recombinant isolates. Until the 1970s, PVY isolates that were not necrotic in tobacco (i.e., belonging to clades $\mathrm{O}$ or $\mathrm{C}$ ) were largely predominant in potato crops in Europe (e.g., approximately $90 \%$ of isolates in France) (Kerlan et al. 1987; Rolland et al. 2008). More recently, the prevalence of isolates from clade $\mathrm{O}$ has decreased largely in European potato crops, while isolates from clade $\mathrm{C}$ tended to become extinct (Blanco-Urgoiti et al. 1998b; Browning et al. 2004; Rolland et al. 2008). In contrast, isolates from clade $\mathrm{N}$ and $\mathrm{N} \times \mathrm{O}$ recombinant isolates have become predominant in The Netherlands, Germany, France, Belgium, the Czech Republic, and Tunisia, and have increased in prevalence in the United States and Canada (Dedic et al. 2007; Djilani-Khouadja et al. 2010; Lindner and Billenkamp 2005; Rolland et al. 2008; Rolot 2007). The widespread presence of the resistance genes $N c_{\text {tbr }}$ and $N y_{\text {tbr }}$ in potato cultivars (Cockerham 1970; Jones 1990) could have been partly responsible for these changes because they target isolates of clades $\mathrm{C}$ and $\mathrm{O}$, respectively.

Because the HC-Pro cistron of PVY isolates of clade $\mathrm{O}$ is the elicitor of the resistance controlled by the $N y_{\text {tbr }}$ gene, we hypothesize that the $N y_{\mathrm{tbr}}$ resistance could have been responsible for the worldwide emergence of $\mathrm{N} \times \mathrm{O}$ recombinant isolates belonging to the "NTN" and "Wilga" groups in potato crops (Schubert et al. 2007). Indeed, emergent $\mathrm{N} \times \mathrm{O}$ recombinant isolates of the NTN and Wilga groups have remarkable common characteristics: i) they possess an HC-Pro cistron which is almost completely of "N" type; ii) they show a recombination breakpoint at the $3^{\prime}$ terminal extremity of the HC-Pro cistron, near the boundary with the P3 cistron (Glais et al. 2002; Schubert et al. 2007); and iii) they are virulent toward the $N y_{\mathrm{tbr}}$ resistance (Blanchard et al. 2008; Rolland et al. 2008). Conse- 
quently, the $N y_{\text {tbr }}$ resistance could have selected PVY isolates with these particular patterns of recombination instead of other kinds of recombinants because the HC-Pro cistron is an avirulence factor corresponding to $N y_{\mathrm{tbr}}$. Consequently, emergence of PVY recombinant isolates with a genome essentially of the $\mathrm{O}$ type, except parts of the P1 and HC-Pro cistrons (Fig. 2C), could constitute one of the rare examples of the breakdown of a resistance gene $\left(N y_{\mathrm{tbr}}\right)$ by a virus (clade O of PVY isolates) which was caused by recombination instead of by successive accumulation of nucleotide substitutions (Diaz et al. 2004).

\section{MATERIALS AND METHODS}

\section{Plant and virus material.}

A genetic analysis of potato resistance to PVY was carried out on 189 diploid $F_{1}$ hybrid clones from a cross between spl329.18, a diploid clone of the $S$. sparsipilum (Bitter) Juz. \& Bukasov accession PI310984 from the Sturgeon Bay collection, which was used as the male parent, and Caspar H3 $(2 \times=2 n=$ 24), a dihaploid of $S$. tuberosum L. Caspar $(4 \times=2 n=48)$ obtained by in situ parthenogenesis (Hougas et al. 1958), which was used as the female parent. King Edward was used as the reference $S$. tuberosum genotype for the $N c_{\mathrm{tbr}}$ gene and Pentland Crown and Désirée were used as the reference $S$. tuberosum genotypes for the $N y_{\text {tbr }}$ gene (Jones 1990). In some experiments, the PVY-susceptible $S$. tuberosum Safrane was used as a control.

The N605, O139, and SON41p isolates which belong to the PVY clades $\mathrm{N}, \mathrm{O}$, and $\mathrm{C} 1$, respectively, were described previously (Moury 2010). The O-Scotland and C-Scotland isolates were obtained from potato crops in Scotland and belong to the $\mathrm{O}$ and $\mathrm{C} 2$ clades, respectively, based on partial genome sequencing (accession numbers AY691546 and AF227515, respectively).

\section{Inoculation procedure and virus detection.}

Plants were grown in greenhouse conditions before and after virus inoculations, with temperature varying between 20 and $28^{\circ} \mathrm{C}$ and with natural light. Virus isolates were propagated in $N$. clevelandii plants to obtain high-titer inocula for tests on Solanum spp. plants. Leaf tissue from infected $N$. clevelandii plants developing systemic mosaic symptoms was homogenized in four volumes per gram of $0.03 \mathrm{M}$ phosphate buffer ( $\mathrm{pH} 7.0$ ) supplemented with $0.2 \%$ (wt/vol) diethyldithiocarbamate, active charcoal at $20 \mathrm{mg} / \mathrm{ml}$, and Carborundum at 20 $\mathrm{mg} / \mathrm{ml}$. Young plants with approximately four expanded leaves were inoculated manually 3 weeks after tuber planting or after transplanting in vitro shoots. Three leaves were inoculated manually. Symptoms were recorded between 14 and 30 dpi. Evaluation of virus infections in apical leaves was performed by DAS-ELISA as described by Moury and associates (2004) at 20 and $30 \mathrm{dpi}$. Absorbance values at $405 \mathrm{~nm}\left(\mathrm{~A}_{405}\right)$ were considered for analysis and samples were considered positive when their $\mathrm{A}_{405}$ was higher than three times the mean $\mathrm{A}_{405}$ of at least five noninoculated samples.

For each spl329.18 $\times$ Caspar $\mathrm{H}_{3} \mathrm{~F}_{1}$ hybrid clone, four plants were inoculated with the C-Scotland and SON41p isolates in two independent experiments. In addition, inoculations of detached leaves of these clones were performed with the same two PVY isolates (four independent experiments were conducted with three leaves per $\mathrm{F}_{1}$ hybrid clone and per virus isolate). One plant (one leaf) per genotype was mock-inoculated with buffer for each greenhouse (detached leaf) experiment.

\section{Mapping the $N c_{\mathrm{spl}}$ resistance gene in the potato genome.}

The RFLP probe TG506 was amplified as described by Park and associates (2005). A CAPS marker at this locus was re- vealed between spl329.18 and Caspar H3 by digestion of the polymerase chain reaction (PCR) product with the endonuclease HindIII and gel electrophoresis. The $N c_{\text {spl }}$ resistance gene and the TG506 CAPS marker were mapped on the framework map of spl329.18 described by Caromel and associates (2005) applying the software MapMaker/Exp version 3.0 (Lander et al. 1987).

\section{Building PVY chimeras and mutants.}

The infectious cDNA clone of isolate SON41p used here was described earlier (Ayme et al. 2006; Moury et al. 2004). The infectious cDNA clone of isolate N605 (Bukovinszki et al. 2007; Jakab et al. 1997) was modified to include a cassette containing the $2-\mu$ yeast replication origin and a selectable marker (Trp- 1 promoter and gene) as described by FernandezDelmond and associates (2004) and Ayme and associates (2006). Chimeras 1 and 2 between SON41p and N605 (Fig. 2) were created by ligating together restriction fragments of the two cDNA clones. A similar strategy, using overlapping restriction fragments of the two cDNA clones and homologous recombination in yeast as described by Fernandez-Delmond and associates (2004), was used to generate chimeras 3 and 4 (Fig. 2A). For the other chimeras between N605 and SON41p, the internal part of the HC-Pro cistron of the N605 and SON41p clones (nucleotides 1,017 to 2,388, according to the sequence of N605, accession number X97895) was deleted by reverse PCR, and a unique NotI restriction site was introduced at the junction, yielding the acceptor shuttle vectors. The cDNA clone of N605 was mutated at nucleotide position 2,101 (adenosine to guanosine substitution changing the isoleucine at position 363 of the HC-Pro to a valine) using the QuikChange sitedirected mutagenesis kit (Stratagene, La Jolla, CA, U.S.A.). Yeast was cotransformed with the above vectors linearized with NotI and with i) cDNA fragments of the HC-Pro cistron containing the $A_{2101} G$ nucleotide substitution to be introduced into N605 for chimera number 8, ii) cDNA fragments of the whole HC-Pro cistron of the other parental virus to build chimeras 5 and 6, iii) overlapping cDNA fragments of the HCPro cistrons of N605 and SON41p for chimera numbers 7 and 9 to 11 , or iv) cDNA fragments of the whole HC-Pro cistron of virus isolates of PVY clade O (O-Scotland or O139) to build chimeras 12 and 13, respectively (Fig. 2B and C). The recombinant plasmids obtained in yeast were further amplified in Escherichia coli XL1 Blue or DH5 $\alpha$. The recombined regions were sequenced to check their conformity or to locate more precisely the recombination site.

The entire sequence of the HC-Pro cistron of the progeny of the PVY chimeras that were recombined in that genome region was determined to exclude the possibility that second-site mutations in this region had modified the pathogenicity properties of the virus. Sequencing was performed directly on reversetranscription PCR products obtained with RNAs purified from apical leaves of at least two plants of spl329.18, King Edward, Caspar H3, Désirée, Pentland Crown, and N. clevelandii per chimera or mutant (Tables 2, 3 and 4).

\section{ACKNOWLEDGMENTS}

We thank N. Lama, A.-G. Bellec, and P. Rousselle (INRA Avignon, France) for help during experiments and A. Thomas and F. Dale (SCRI, Scotland) for the gift of Pentland Crown tubers.

\section{LITERATURE CITED}

Asama, K., Ito, H., Murakami, N., and Itoh, T. 1982. New potato variety "Konafubuki". Bull. Hokkaido Pref. Agric. Exp. Stn. 48:75-84.

Ayme, V., Souche, S., Caranta, C., Jacquemond, M., Chadœuf, J., Palloix, A., and Moury, B. 2006. Different mutations in the genome-linked pro- 
tein VPg of Potato virus $Y$ confer virulence on the $p v r 2^{3}$ resistance in pepper. Mol. Plant-Microbe Interact. 19:557-563.

Bendahmane, A., Köhm, B. A., Dedi, C., and Baulcombe, D. C. 1995. The coat protein of potato virus $\mathrm{X}$ is a strain-specific elicitor of $R x 1$-mediated virus resistance in potato. Plant J. 8:933-941.

Bendahmane, A., Kanyuka, K., and Baulcombe, D. C. 1999. The $R x$ gene from potato controls separate virus resistance and cell death responses. Plant Cell 11:781-791.

Bhattacharjee, S., Zamora, A., Azhar, M. T., Sacco, M. A., Lambert, L. H., and Moffett, P. 2009. Virus resistance induced by NB-LRR proteins involves Argonaute4-dependent translational control. Plant J. 58:940-951.

Blanchard, A., Rolland, M., Lacroix, C., Kerlan, C., and Jacquot E. 2008. Potato virus Y: A century of evolution. Curr. Top. Virol. 7:21-32.

Blanco-Urgoiti, B., Sanchez, F., Perez de san Roman, C., Dopazo, J., and Ponz, F. 1998a. PVY C isolates are a homogeneous pathotype but two different genetic strains. J. Gen. Virol. 79:2037-2042.

Blanco-Urgoiti, B., Tribodet, M., Leclere, S., Ponz, F., Pérez de San Román, C., Legorburu, F. J., and Kerlan, C. 1998b. Characterization of potato potyvirus Y (PVY) isolates from seed potato batches. Situation of the NTN, Wilga and Z isolates. Eur. J. Plant Pathol. 104:811-819.

Brigneti, G., Voinnet, O., Li, W. X., Ji, L. H., Ding, S. W., and Baulcombe, D. C. 1998. Viral pathogenicity determinants are suppressors of transgene silencing in Nicotiana benthamiana. EMBO (Eur. Mol. Biol. Organ.) J. 17:6739-6746.

Browning, I., Fox, A., Holmes, R., Mulholland, V., and Darling, D. 2004 Variability in Potato virus $Y$ in seed potato crops in Scotland. Page 3 in: 12th EAPR Virol. Sect. Meet. Rennes, France.

Bukovinszki, A., Götz, R., Johansen, E., and Balázs, E. 2007. The role of the coat protein region in symptom formation on Physalis floridana varies between PVY strains. Virus Res. 127:122-125.

Burch-Smith, T. M., Schiff, M., Caplan, J. L., Tsao, J., Czymmek, K., and Dinesh-Kumar, S. P. 2007. A novel role for the TIR domain in association with pathogen-derived elicitors. PloS Biol. 5:e68. Published online.

Cadman, C. H. 1942. Autotetraploid inheritance in the potato: Some new evidence. J. Genet. 44:33-52.

Caromel, B., Mugniéry, D., Kerlan, M.-C., Andrzejewski, S., Palloix, A., Ellissèche, D., Rousselle-Bourgeois, F., and Lefebvre, V. 2005. Resistance quantitative trait loci originating from Solanum sparsipilum act independently on the sex ratio of Globodera pallida and together for developing a necrotic reaction. Mol. Plant-Microbe Interact. 18:11861194.

Celebi-Toprak, F., Slack, S. A., and Jahn, M. M. 2002. A new gene, $N y_{\mathrm{tbr}}$, for hypersensitivity to Potato virus $Y$ from Solanum tuberosum maps to chromosome IV. Theor. Appl. Genet. 104:669-674.

Chowda-Reddy R. V., Sun, H., Chen, H., Poysa, V., Ling, H., Gijzen, M., and Wang, A. 2011. Mutations in the P3 protein of Soybean mosaic virus G2 isolates determine virulence on Rsv4-genotype soybean. Mol. Plant-Microbe Interact. 24:37-43.

Cockerham, G. 1943. Potato breeding for virus resistance. Ann. Appl Biol. 30:105-108.

Cockerham, G. 1970. Genetical studies on resistance to potato viruses X and Y. Heredity 25:309-348.

De Bokx, J. A., and Huttinga, H. 1981. Potato virus Y. Page 242 in: CMI/ AAB Descriptions of Plant Viruses. Commonwealth Institute/Association of Applied Biologists, Kew, Surrey, England.

Dedic, P., Ptacek, J., and Cerovska, N. 2007. A shift of PVY strain spectrum on potatoes in CR in the course of past years. Page 59 in: 13th EAPR Virol. Sect. Meet. Coylumbridge, Aviemore, Scotland, U.K.

Diaz, J., Nieto, C., Moriones, E., Truniger, V., and Aranda, M. 2004. Molecular characterization of a Melon necrotic spot virus strain that overcomes the resistance in melon and nonhost plants. Mol. PlantMicrobe Interact. 17:668-675.

Djilani-Khouadja, F., Glais, L., Tribodet, M., Kerlan, C., and Fakhfakh, H. 2010. Incidence of potato viruses and characterisation of Potato virus $Y$ variability in late season planted potato crops in northern Tunisia. Eur. J. Plant Pathol. 126:479-488.

Edwardson, J. R., and Christie, R. G. 1997. Fla. Agric. Exp. Stn. Monogr. Ser. 18:467.

Eggenberger, A. L., Hajimorad, M. R., and Hill, J. H. 2008. Gain of virulence on Rsv1-genotype soybean by an avirulent Soybean mosaic virus requires concurrent mutations in both P3 and HC-Pro. Mol. Plant-Microbe Interact. 21:931-936.

Fernandez-Delmond, I., Pierrugues, O., De Wispelaere, M., Guilbaud, L., Gaubert, S., Diveki, Z., Godon, C., Tepfer, M., and Jacquemond, M. 2004. A novel strategy for creating recombinant infectious RNA virus genomes. J. Virol. Methods 121:247-257.

Flis, B., Hennig, J., Strzelczyk-Żyta, D., Gebhardt, C., and Marczewski, W. 2005. The $R y-f_{\text {sto }}$ gene from Solanum stoloniferum for extreme resistant to Potato virus $Y$ maps to potato chromosome XII and is diagnosed by PCR marker GP122718 in PVY resistant potato cultivars.
Mol. Breed. 15:95-101.

Glais, L., Tribodet, M., and Kerlan, C. 2002. Genomic variability in Potato potyvirus Y (PVY): Evidence that (PVYW)-W-N and PVYNTN variants are single to multiple recombinants between $\mathrm{PVY}^{\mathrm{O}}$ and $\mathrm{PVY}^{\mathrm{N}}$ isolates. Arch. Virol. 147:363-378.

Grattapaglia, D., and Sederoff, R. 1994. Genetic linkage maps of Eucalyptus grandis and Eucalyptus urophylla using a pseudo-testcross: Mapping strategy and RAPD markers. Genetics 137:1121-1137.

Hämäläinen, J. H., Watanabe, K. N., Valkonen, J. P. T., Arihara, A., Plaisted, R. L., Pehu, E., Miller, L., and Slack, S. A. 1997. Mapping and marker-assisted selection for a gene for extreme resistance to potato virus Y. Theor. Appl. Genet. 94:192-197.

Harrison, B. D. 2002. Virus variation in relation to resistance-breaking in plants. Euphytica 124:181-192.

Hougas, R. W., Peloquin, S. J., and Ross, S.W. 1958. Haploids of the common potato. J. Hered. 49:103-106.

Jakab, G., Droz, E., Brigneti, G., Baulcombe, D., and Malnoë, P. 1997. Infectious in vivo and in vitro transcripts from a full-length cDNA clone of PVY-N605, a Swiss necrotic isolate of Potato virus Y. J. Gen. Virol. 78:3141-3145.

Janzac, B., Fabre, F., Palloix, A., and Moury, B. 2009. Constraints on evolution of virus avirulence factors predict the durability of corresponding plant resistances. Mol. Plant Pathol. 10:599-610.

Janzac, B., Montarry, J., Palloix, A., Navaud, O., and Moury B. 2010. A point mutation in the polymerase of Potato virus $Y$ confers virulence towards the Pvr4 resistance of pepper and a high competitiveness cost in susceptible cultivar. Mol. Plant-Microbe Interact. 23:823-830.

Jones, R. A. C. 1990. Strain group specific and virus specific hypersensitive reactions to infection with potyviruses in potato cultivars. Ann. Appl. Biol. 117:93-105.

Kerlan, C., and Moury, B. 2008. Potato virus Y. Pages 287-296 in: Encyclopedia of Virology, third edition. A. Granoff and R. Webster, eds Academic Press, New York.

Kerlan, C., Robert, Y., Perennec, P., and Guillery, E. 1987. Mise au point sur l'incidence du virus $\mathrm{Y}^{\circ}$ et méthodes de lutte mises en oeuvre en France pour la production de semences de pommes de terre. Potato Res. 30:651-667.

Lander, E., Green, P., Abrahamson, J., Barlow, A., Daley, M., Lincoln, S., and Newburg, L. 1987. MAPMAKER: An interactive computer package for constructing primary genetic linkage maps of experimental and natural populations. Genomics 1:174-181.

Lindner, K., and Billenkamp, N. 2005. Changes in the spectrum of PVY strains and strain groups: Could this be a cause for the increase of virus susceptibility of potato and tobacco varieties? Nachrichtenbl. Dtsch. Pflanzenschutzdienstes (Braunschweig) 57:245-253.

Mestre, P., Brigneti, G., and Baulcombe, D. C. 2000. An Ry-mediated resistance response in potato requires the intact active site of the $\mathrm{Nia}$ proteinase from Potato virus Y. Plant J. 23:653-661.

Mestre, P., Brigneti, G., Durrant, M. C., and Baulcombe, D. C. 2003. Potato virus Y Nia protease activity is not sufficient for elicitation of $R y$-mediated disease resistance in potato. Plant J. 36:755-761.

Moury, B. 2010. A new lineage sheds light on the evolutionary history of Potato virus Y. Mol. Plant Pathol. 11:161-168.

Moury, B., Morel, C., Johansen, E., Guilbaud, L., Souche, S., Ayme, V., Caranta, C., Palloix, A., and Jacquemond, M. 2004. Mutations in Potato virus $Y$ genome-linked protein determine virulence towards recessive resistances in Capsicum annuum and Lycopersicon hirsutum. Mol. Plant-Microbe Interact. 17:322-329.

Oh, C.-S., and Carrington, J. C. 1989. Identification of essential residues in potyvirus proteinase $\mathrm{HC}$-pro by site-directed mutagenesis. Virology 173:692-699.

Park, T. H., Gros, J., Sikkema, A., Vleeshouwers, V., Muskens, M., Allefs, S., Jacobsen, E., Visser, R. G. F., and van der Vossen, E. A. G. 2005 The late blight resistance locus Rpi-blb3 from Solanum bulbocastanum belongs to a major late blight $\mathrm{R}$ gene cluster on chromosome 4 of potato. Mol. Plant-Microbe Interact. 18:722-729.

Ragsdale, D.,W., Radcliffe, E. B., and DiFonzo, C. D. 2001. Epidemiology and field control of PVY and PLRV. Pages 237-270 in: Virus and Virus-Like Diseases of Potatoes and Production of Seed-Potatoes. G. Loebenstein, P. Berger, A. A. Brunt, and R. G. Lawson, eds. Kluwer Academic Publishers, Dordrecht, The Netherlands.

Revers, F., Le Gall, O., Candresse, T., Le Romancer, M., and Dunez, J. 1996. Frequent occurrence of recombinant potyvirus isolates. J. Gen. Virol. 77:1953-1965.

Rolland, M., Lacroix, C., Blanchard, A., Baldwin, T., Kerlan, C., and Jacquot, E. 2008. Potato virus $Y$ (PVY): From its discovery to the latest outbreaks. Virologie 12:261-273.

Rolot, J. L. 2007. Balance between $\mathrm{PVY}^{\mathrm{N}}$ and $\mathrm{PVY}^{\mathrm{O}}$ strains in Belgium: First approaches. Page 70 in: 13 EAPR Virology Section Meeting, Coylumbridge, Aviemore, Scotland, U.K. 
Ross, H. 1986. Potato breeding-problems and perspectives. J. Plant Breed. Suppl. 13.

Sáenz, P., Salvador, B., Simón-Mateo, C., Kasschau, K. D., Carrington, J. C., and García, J. A. 2002. Host-specific involvement of the HC protein in the long-distance movement of potyvirus. J. Virol. 76:1922-1931.

Sato, M., Nishikawa, K., Komura, K., and Hosaka, K. 2006. Potato virus $Y$ resistance gene, $R y_{c h c}$, mapped to the distal end of potato chromosome 9. Euphytica 149:367-372.

Schirmer, A., Link, D., Cognat, V., Moury, B., Beuve, M., Meunier, A., Bragard, C., Gilmer, D., and Lemaire, O. 2005. Phylogenetic analysis of isolates of beet necrotic yellow vein virus collected worldwide. J. Gen. Virol. 86:2897-2911.

Schubert, J., Fomitcheva, V., and Sztangret-Wisniewska, J. 2007. Differentiation of Potato virus $Y$ strains using improved sets of diagnostic PCRprimers. J. Virol. Methods 140:66-74.

Shiboleth, Y. M., Haronsky, E., Leibman, D., Arazi, T., Wassenegger, M., Whitham, S. A., Gaba, V., and Gal-On, A. 2007. The conserved FRNK box in HC-Pro, a plant viral suppressor of gene silencing, is required for small RNA binding and mediates symptom development. J. Virol. $81: 13135-13148$.

Song, Y.-S., Hepting, L., Schweizer, G., Hartl, L., Wenzel, G., and Schwarzfischer, A. 2005. Mapping of extreme resistance to PVY $\left(R y_{\text {sto }}\right)$ on chromosome XII using anther-culture-derived primary dihaploid potato lines. Theor. Appl. Genet. 111:879-887.

Szajko, K., Chrzanowska, M., Witek, K., Strzelczyk-Żyta, D., Zagórska, H., Gebhardt, C., Hennig, J., and Marczewski, W. 2008. The novel gene $N y-1$ on potato chromosome IX confers hypersensitive resistance to Potato virus $Y$ and is an alternative to $R y$ genes in potato breeding for
PVY resistance. Theor. Appl. Genet. 116:297-303.

Szittya, G., and Burgyán, J. 2001. Cymbidium ringspot tombusvirus coat protein coding sequence acts as an avirulent RNA. J. Virol. 75:24112420.

Torres-Barcelo, C., Martin, S., Daros, J. A., and Elena, S. F. 2008. From hypo- to hypersuppression: Effect of amino acid substitutions on the RNA-silencing suppressor activity of the tobacco etch potyvirus HCPro. Genetics 180:1039-1049.

Tribodet, M., Glais, L., Kerlan, C., and Jacquot, E. 2005. Characterization of Potato virus $Y$ (PVY) molecular determinants involved in the vein necrosis symptom induced by $\mathrm{PVY}^{\mathrm{N}}$ isolates in infected Nicotiana tabacum cv. Xanthi. J. Gen. Virol. 86:2101-2105.

Urcuqui-Inchima, S., Haenni, A. L., and Bernardi, F. 2001. Potyvirus proteins: A wealth of functions. Virus Res. 74:157-175.

Valkonen, J. P. T., Wiegmann, K., Hämäläinen, J. H., Marczewski, W., and Watanabe, K. N. 2008. Evidence for utility of the same PCR-based markers for selection of extreme resistance to Potato virus $Y$ controlled by $R y_{\text {sto }}$ of Solanum stoloniferum derived from different sources. Ann. Appl. Biol. 152:121-130.

Varrelmann, M., Maiss, E., Pilot, R., and Palkovics, L. 2007. Use of pentapeptide-insertion scanning mutagenesis for functional mapping of the Plum pox virus helper component proteinase suppressor of gene silencing. J. Gen. Virol. 88:1005-1015.

Yambao, M. L. M., Yagihashi, H., Sekiguchi, T., Sasaki, T., Sato, M., Atsumi, G., Tacahashi, Y., Nakahara, K. S., and Uyeda, I. 2008. Point mutations in helper component protease of Clover yellow vein virus are associated with the attenuation of RNA silencing suppression activity and symptom expression in broad bean. Arch. Virol. 153:105-115. 